\title{
PERANCANGAN MODEL LEARNING MANAGEMENT SYSTEM UNTUK SEKOLAH
}

\author{
Natalia Limantara; Fredy Jingga \\ Information Systems Department, School of Information Systems, Binus University \\ Jl. K.H. Syahdan No. 9, Palmerah, Jakarta Barat 11480 \\ nlimantara@binus.edu,fjingga@binus.edu
}

\begin{abstract}
Designing a Learning Management System models are useful for schools to assist in teaching and learning. Learning Management System makes the teachers and students can interact with one another without being limited by space and time. Learning Management System was developed using the agile methodology and using the PHP programming language. Data management in a learning management system is using My SQL. Model application's Learning Management System, created web-based, with the aim to enable teachers and students who become a model user of this application, to access lesson plans and learning materials via the internet wherever they are.
\end{abstract}

Keywords : Learning Management System, PHP, MySQL, Forum

\begin{abstract}
ABSTRAK
Perancangan model Learning Management System untuk sekolah adalah bermanfaat untuk membantu dalam proses belajar mengajar. Learning Management System membuat para guru dan siswa bisa berinteraksi satu dengan yang lain tanpa dibatasi oleh ruang dan waktu. Learning Management System ini dikembangkan menggunakan metodologi agile dan menggunakan bahasa pemrograman PHP. Manajemen data dalam learning management system adalah menggunakan My SQL. Model aplikasi Learning Management System ini, dibuat berbasis web, dengan tujuan untuk memungkinkan guru dan siswa yang menjadi user model aplikasi ini, untuk mengakses perencanaan pembelajaran dan materi pembelajaran melalui internet di mana saja mereka berada. Di samping akses materi pembelajaran, Learning management system ini membantu para user untuk bisa mendiskusikan topik topik secara on-line menggunakan forum yang telah disediakan.
\end{abstract}

Kata kunci: Learning Management System, PHP, MySQL, Forum 


\section{PENDAHULUAN}

Saat ini perkembangan teknologi informasi sudah sangat pesat. Pemanfaatan teknologi telah mempengaruhi berbagai macam aspek kehidupan. Salah satunya, teknologi sudah mulai memasuki dunia pendidikan mulai dari pendidikan tingkat dasar hingga tingkat atas. Pada tingkat dasar yaitu sekolah dasar hingga sekolah menengah atas, guru saat ini sudah mulai memahami betapa penting penggunaan teknologi untuk membantu proses belajar mengajar. Teknologi dimanfaatkan untuk mendukung proses belajar mengajar berjalan dengan lebih efektif dan efisien. Komunikasi yang terjalin antara guru dan siswa tidak hanya terbatas pada ruang kelas namun sudah bergeser dengan pemanfaatan teknologi di luar kelas. Guru dapat berkomunikasi dengan siswa melalui internet dengan memanfaat aplikasi-aplikasi yang saat ini tersedia. Berdasarkan survei yang pernah dilakukan oleh O’Keeffe \& Co. pada tahun 2012 yang lalu terhadap 1015 responden terdiri dari 410 siswa, 340 guru, dan 301 staff IT di sekolah, diketahui bahwa 75\% dari siswa dan 72\% dari guru sudah menggunakan notebook atau netbook di dalam kelas sebagai alat pembelajaran.

Masih berdasarkan survei yang sama, 69\% siswa dan 73\% guru sudah menggunakan materi pembelajaran dalam bentuk digital serta 56\% dari responden sudah melibatkan penggunakan Learning Management System (LMS) di dalam kelas. Dengan perkembangan teknologi ini, tuntutan untuk menyampaikan materi tidak hanya terbatas pada ruangan kelas semakin meningkat. Guru diharapkan dapat hadir diluar kelas dengan memanfaatkan teknologi yang ada seperti fasilitas Learning Management System. Proses pembelajaran dengan memanfaatkan bantuan dari Learning Management System dirasakan sangat membantu. Siswa dapat berinteraksi dengan guru selama 24 jam melalui email atau forum diskusi, atau melalui fasilitas yang disediakan oleh LMS. Dan siswa dapat menjadi lebih aktif dengan mencari sumber-sumber informasi lain tidak hanya melalui guru namun dapat dilengkapi melalui sumber-sumber lain. Gambar 1 berikut menjelaskan perbandingan antara proses pembelajaran tradisional dan dengan pembelajaran memanfaatkan LMS.

Dengan semakin pentingnya penggunaan LMS di dalam proses pembelajaran, penulis mencoba untuk merancang sebuah model aplikasi LMS yang dapat diterapkan oleh sekolah. Tujuan dari perancangan ini adalah mengahasilkan sebuah model LMS yang dapat diterapkan mulai dari pendidikan tingkat dini (TK) hingga pendidikan tingkat atas (SMA). Dan model LMS ini dapat digunakan sebagai sarana komunikasi antara guru dan siswa serta memudahkan dalam pembuatan materi pembelajaran hingga pendistribusiannya.

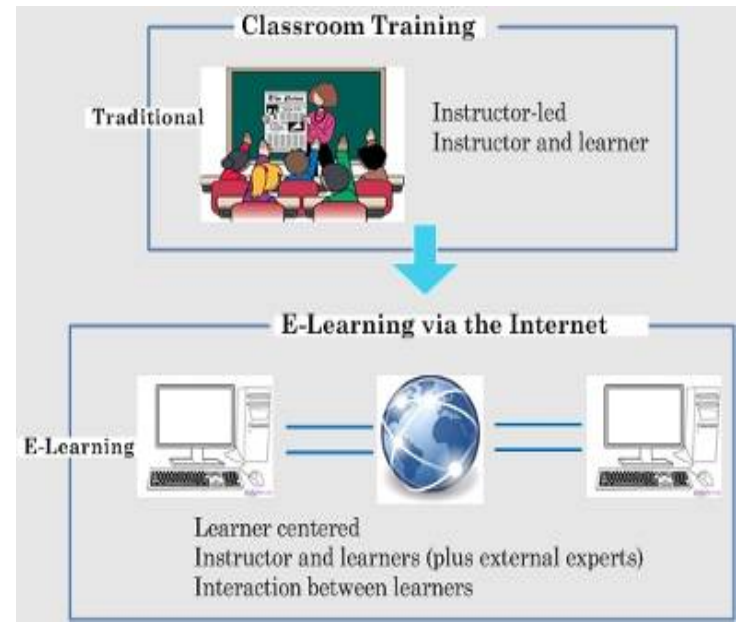

Gambar 1 Perbandingan proses pembelajaran E-Learning dan Tradisional 


\section{Tinjauan Pustaka}

\section{Pengertian e-Learning}

Menurut William Horton (2011), e-learning adalah penggunaan teknologi informasi untuk menciptakan pengalaman belajar. Dalam hal ini teknologi tidak dibatasi pada alat atau sarana tertentu. Penerapan e-learning harus dapat mencakup semua bagian mulai dari kurikulum hingga semua komponen media yang ada di dalamnya. Gambar 2 berkut menjelaskan mengenai komponen di dalam e-Learning secara keseluruhan.

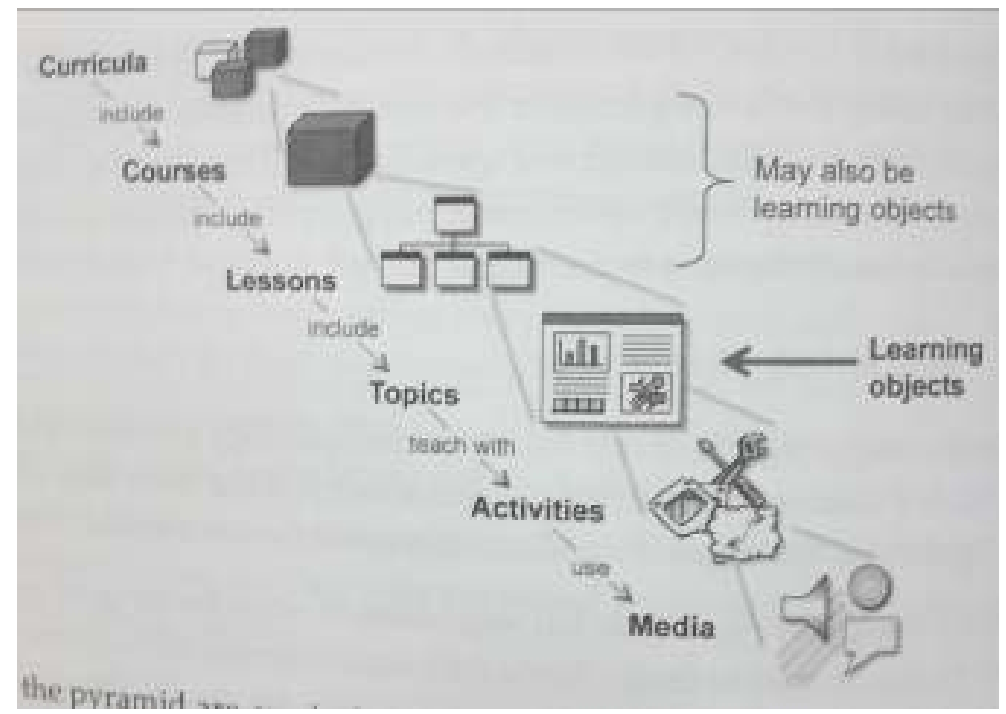

Gambar 2 Bagian dari e-Learning

Bagian teratas adalah kurikulum, program yang terdiri dari course yang berhubungan yang bertujuan untuk mencapai sebuah keahlian dalam area tertentu. Kurikulum terdiri dari course, dimana setiap course mengajarkan pengetahuan tertentu. Course terdiri dari komponen-komponen kecil yang disebut dengan lesson. Setiap lesson disusun untuk mencapai salah satu tujuan dari course. Tingkatan selanjutnya adalah topik, setiap topik dirancang untuk mencapai tujuan pembelajaran yang lebih spesifik.

Aktivitas pembelajaran (learning activities) dirancang untuk menciptakan pengalaman belajar tertentu. Setiap aktivitas dapat menjawab pertanyaan tertentu atau membuat sebuah kesimpulan namun untuk mencapai tujuan pembelajaran tidak cukup hanya dengan satu aktivitas pembelajaran. Aktivitas untuk mengukur apakah sebuah tujuan pembelajaran tercapai disebut dengan tes atau ujian. Bagian akhir adalah media yaitu kalimat, gambar, video, musik, efek suara, atau animasi yang menampilkan aktivitas untuk belajar.

\section{Pengertian Learning Management System}

Learning Management System adalah teknologi berbasis web yang membantu dalam perencanaan, distribusi, dan evaluasi sebuah proses pembelajaran. LMS menyediakan wadah yang terintegrasi untuk materi, penyampaian, dan manajemen pembelajaran yang dapat diakses oleh peserta didik, pembuat materi, dan adimistrator. LMS bertindak sebagai titik pusat dari implementasi $e$ learning. LMS harus dapat mengakomodasi berbagai macam cara penyampaian materi. 


\section{Iterative and Agile System Development Lifecycle}

Agile development adalah sebuah proses pengembangan sistem informasi yang menekankan pada flesibolitas untuk mengantisipasi persyaratan baru selama proses pengembangan sistem. Iterative developement adalah pendekatan pengembangan sistem dimana sistem dibangun bagian per bagian melalui beberapa kali perulangan. Bagian sistem diselesaikan terlebih dahulu kemudian proses diulangi untuk perbaikan dan penambahan hingga semua sistem selesai dibangun. Gambar 3 menjelaskan mengenai aktivitas utama yang harus dilalui jika mengembangkan sebuah sistem informasi menggunakan iterative and agile SDLC.

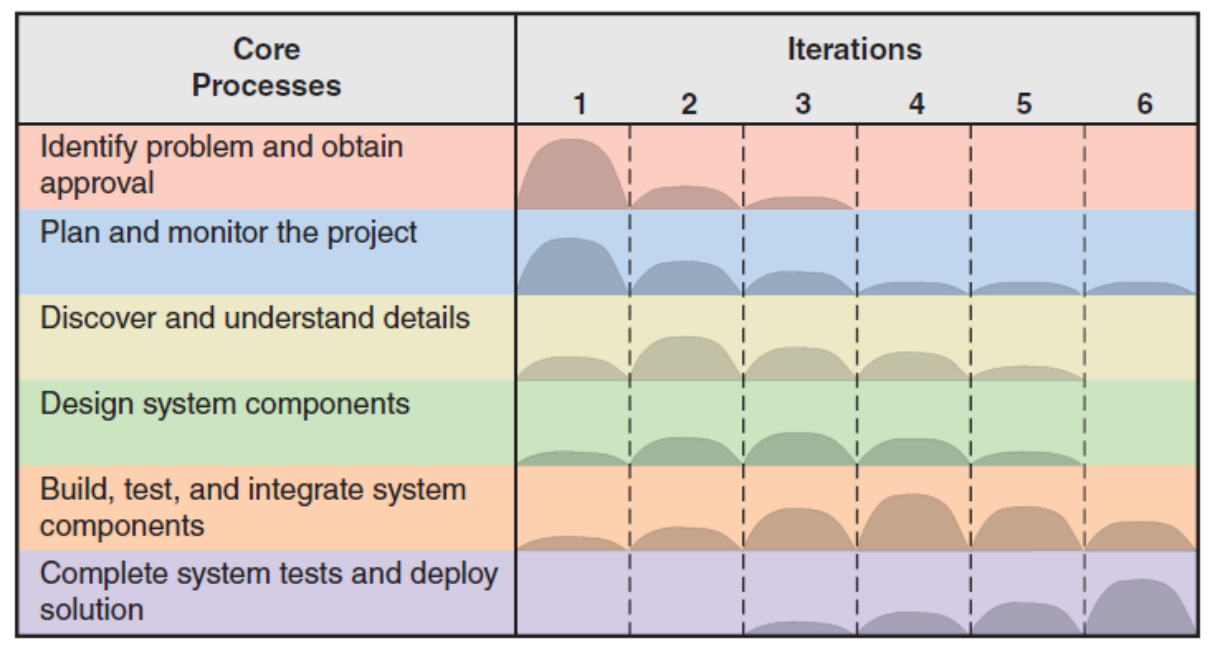

Gambar 3 Iterative and Agile Systems Development Lifecycle

\section{METODE}

Metode yang digunakan dalam penyusunan model Learning Management System untuk sekolah adalah metode iterative and agile systems development lifecycle menurut Satzinger dan Stephen (2012). Berdasarkan metodologi ini, dilakukan tahapan identifikasi masalah mengenai aspek e-learning yang akan ditampilkan di dalam Learning Management System, menganalisa detil model yang diperlukan, dan merancang komponen-komponen sistem yang akan dibuat. Pada tahap ini, akan dihasilkan sebuah model yang dapat diterapkan untuk mengembangkan aplikasi Learning Management System yang dapat digunakan secara umum oleh sekolah yang ada di Indonesia.

\section{HASIL DAN PEMBAHASAN}

Berdasarkan komponen e-Learning yang ada, maka model yang dihasilkan mengacu kepada komponen-komponen e-Learning yang harus ada pada penerapan LMS. Dimulai dari penyiapan course atau mata pelajaran kemudian dilanjutkan dengan persiapan learning outcome atau learning objective atau tujuan dari pembelajaran. Langkah selanjutnya adalah persiapan topik serta media yang akan digunakan untuk penyampaian topik tersebut hingga evaluasi dari topik yang ada dengan pemberian tugas dan kuis. Berdasarkan komponen-komponen tersebut, maka aktivitas yang akan dilakukan dalam LMS ini dapat digambarkan dalam gambar 4. 


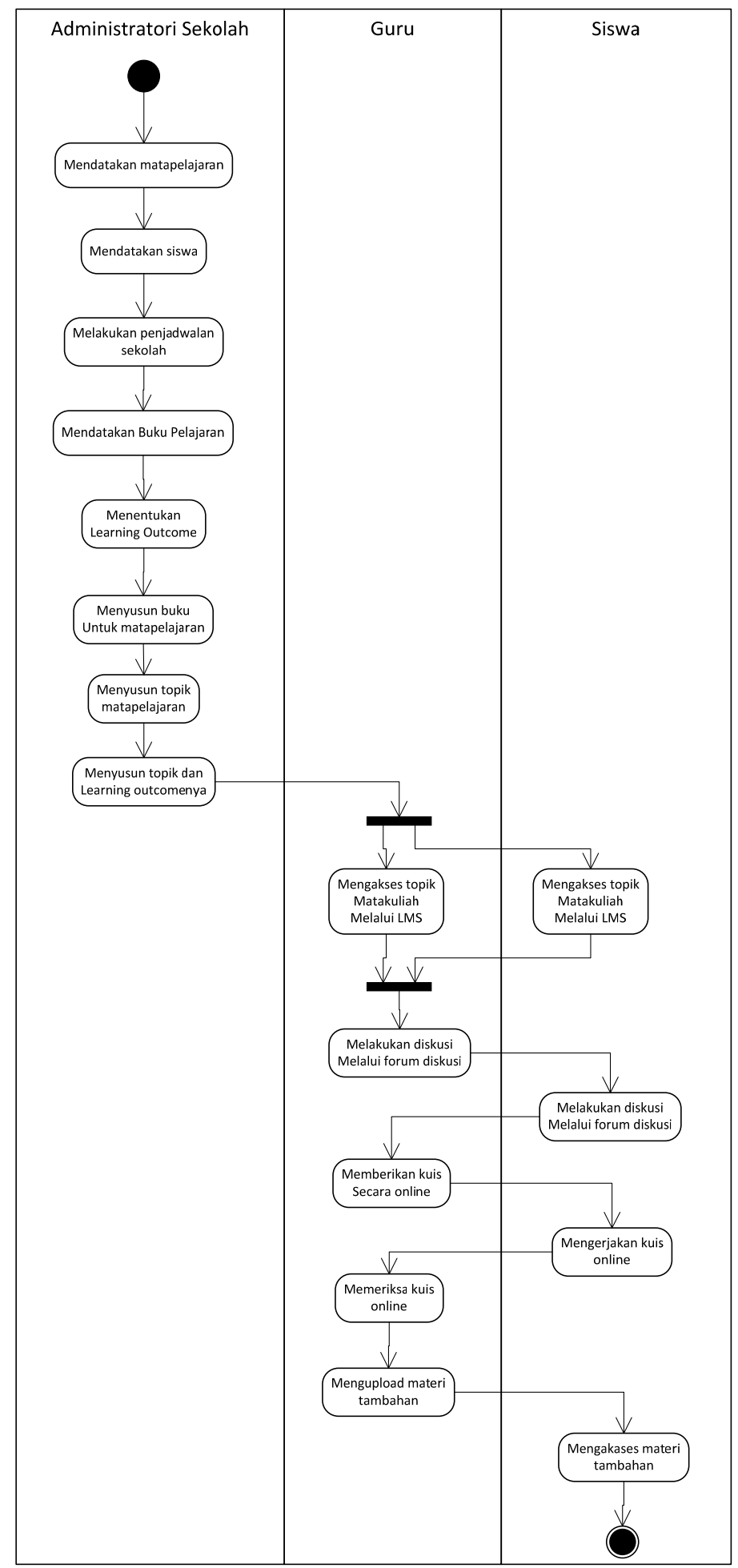

Gambar 4 Activity Diagram untuk Learning Management System

Hal yang harus dilakukan pertama kali di LMS ini adalah mendatakan mata pelajaran yang akan ditambahkan sebagai mata pelajaran di dalam LMS. Selanjutnya administrator sekolah harus mendatakan siswa dan jadwal sekolah untuk menentukan akses ke dalam LMS. Setelah itu administrator sekolah harus mendatakan buku yang akan digunakan di dalam proses pembelajaran. Learning outcome harus ditentukan sebagai panduan dalam penentuan topik mata pelajaran. 
Selanjutnya administrator harus menentukan topik yang akan digunakan di setiap mata pelajaran, learning outcome dari setiap topik dan meng-upload materi yang akan digunakan di setiap topik.

Setelah isi dari LMS dipersiapkan oleh administrator, guru dan siswa dapat mengakses materi setiap mata pelajaran melalui LMS. Guru memiliki akses tambahan untuk menambahkan materi selain dari yang sudah disediakan. Di dalam model sistem LMS ini, siswa dan guru dapat berkomunikasi atau berdiskusi melalui forum diskusi. Guru dapat memberikan kuis dalam bentuk pilihan ganda, jawaban singkat, dan essay melalui LMS ini dan siswa dapat mengupload jawaban siswa. Untuk soal dengan tipe pilihan ganda dan jawaban singkat, akan secara otomatis dinilai oleh siswa, sedangkan untuk soal tipe essay guru yang bersangkutan harus menilai jawaban yang di-upload oleh siswa.

Berdasarkan proses yang telah digambarkan di dalam activity diagram diatas, dapat digambarkan di dalam sebuah use case diagram. Secara umum Learning Management System ini akan dijalankan oleh tiga aktor yaitu administrator sekolah, guru, dan siswa. Tugas utama dari administrator adalah mempersiapkan data awal yang akan digunakan untuk LMS seperti jadwal sekolah, data mata pelajaran, data topik pelajaran, dan materi pembelajaran. Guru dan siswa adalah sebagai pengguna dari LMS di mana guru dan siswa dapat mengakses materi pembelajaran yang telah di-upload oleh administrator. Khusus untuk guru, guru akan memiliki akses tambahan untuk dapat meng-upload materi tambahan selain dari yang sudah diberikan oleh administrator dan dapat memberikan kuis. Sedangkan untuk siswa, siswa dapat menjawab kuis yang sudah diberikan.

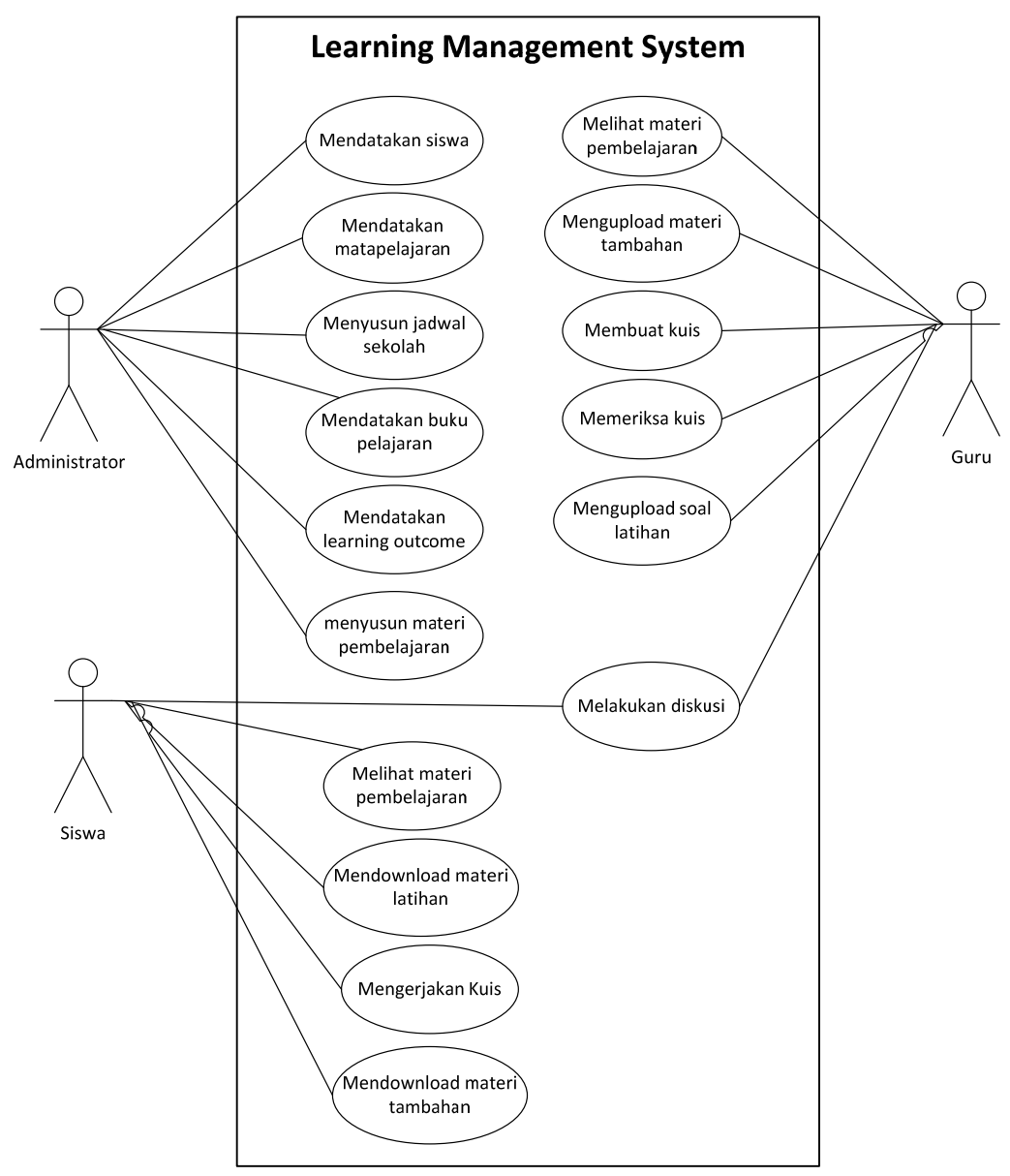

Gambar 5 Use Case Diagram Learning Management System 
Tahapan selanjutnya, perancangan model Learning Management System dilanjutkan dengan merancang domain model class diagram yang dapat digunakan untuk pengembangan model Learning Management System selanjutnya. Domain model class diagram ini dapat digunakan dalam tahapan perancangan selanjutnya. Domain model class diagram ini dapat dijadikan landasan dalam tahapan perancangan database yang akan digunakan oleh Learning Management System ini. Domain class diagram yang digunakan dalam model Learning Management System ini dapat dilihat pada gambar 6.

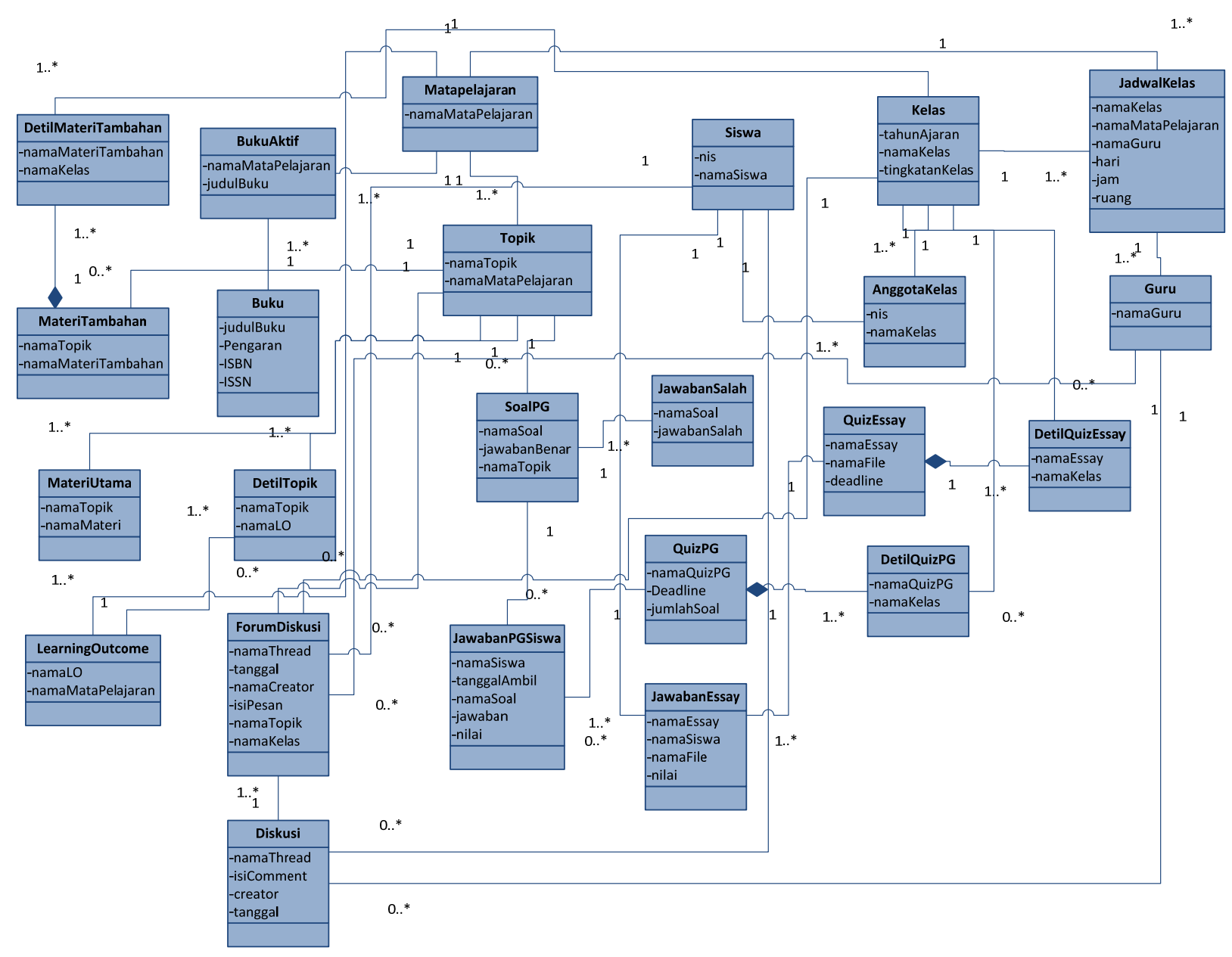

Gambar 6 Domain Class Diagram

Tahapan perancangan model Learning Management System untuk sekolah dilanjutkan pada tahapan perancangan user interface. User interface dirancang sesederhana mungkin untuk memudahkan pengguna dalam menggunakan sistem yang disediakan. Gambar 7 menampilkan rancangan layar untuk mendatakan topik mata pelajaran. Topik harus didatakan setiap tahun ajaran dengan memilih mata pelajar kemudian administrator dapat memilih buku yang akan digunakan pada mata pelajaran tertentu. Setelah menentukan buku, administrator akan menentukan topik-topik yang akan dipelajari oleh siswa dan untuk setiap topik harus ditentukan learning outcome yang berhubungan dengan mengklik tombol mapping. Di dalam setiap topik, administrator dapat mengisi keterangan berupa penjelasan detil mengenai topik dan meng-upload materi yang akan digunakan pada topik tersebut. 


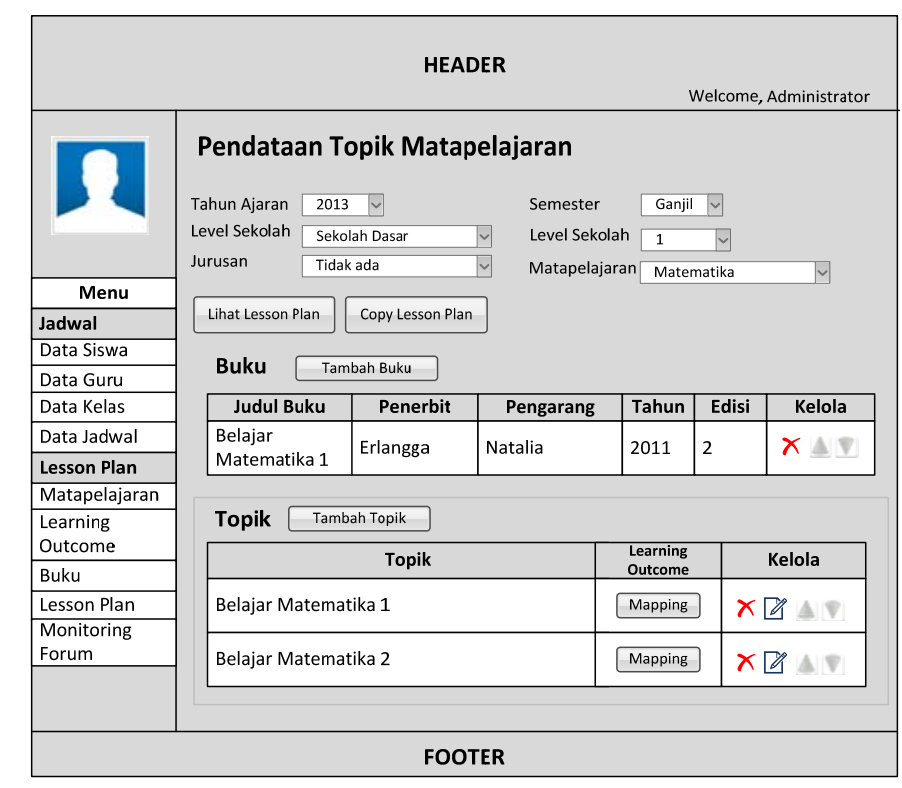

Gambar 7 Rancangan Layar Pendataan Topik Matapelajaran

Guru dan siswa dapat melihat lesson plan yang sudah didata oleh administrator melalui halaman Lesson Plan. Pada halaman ini, guru dan siswa dapat melihat buku yang digunakan, topik yang akan diajarkan, dan men-download materi pembelajaran yang ada. Pada halaman Lihat Lesson Plan guru terdapat tombol untuk meng-upload materi tambahan. Saat meng-upload materi tambahan, guru dapat memilih kelas mana saja yang dapat men-download materi tersebut. Sedangkan siswa hanya dapat men-download materi tambahan yang sudah di-upload oleh guru.

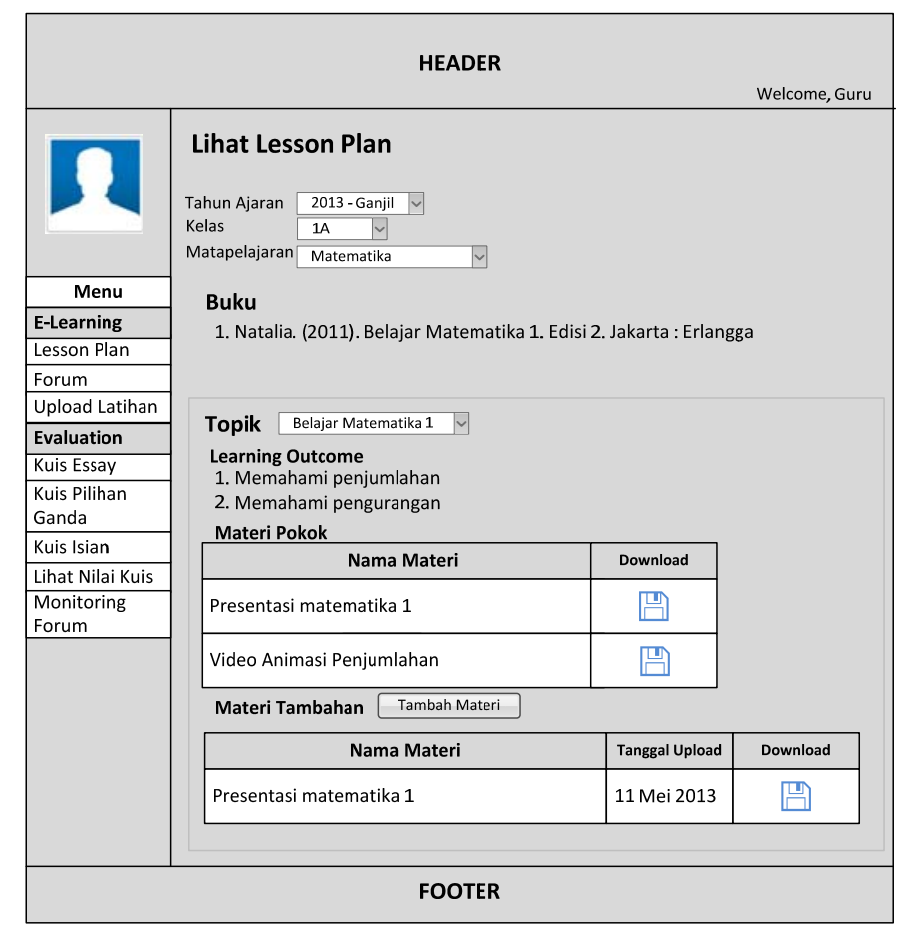

Gambar 8 Rancangan Layar Lesson Plan Guru 
Pada halaman forum, guru dan siswa dapat berdiskusi mengenai topik pada mata pelajaran tertentu. Guru dan siswa dapat membuat topik pembahasan baru dan mengajukan komentar untuk topik pembahasan yang diberikan. Gambar 9 menampilkan rancangan layar forum yang akan digunakan oleh siswa.

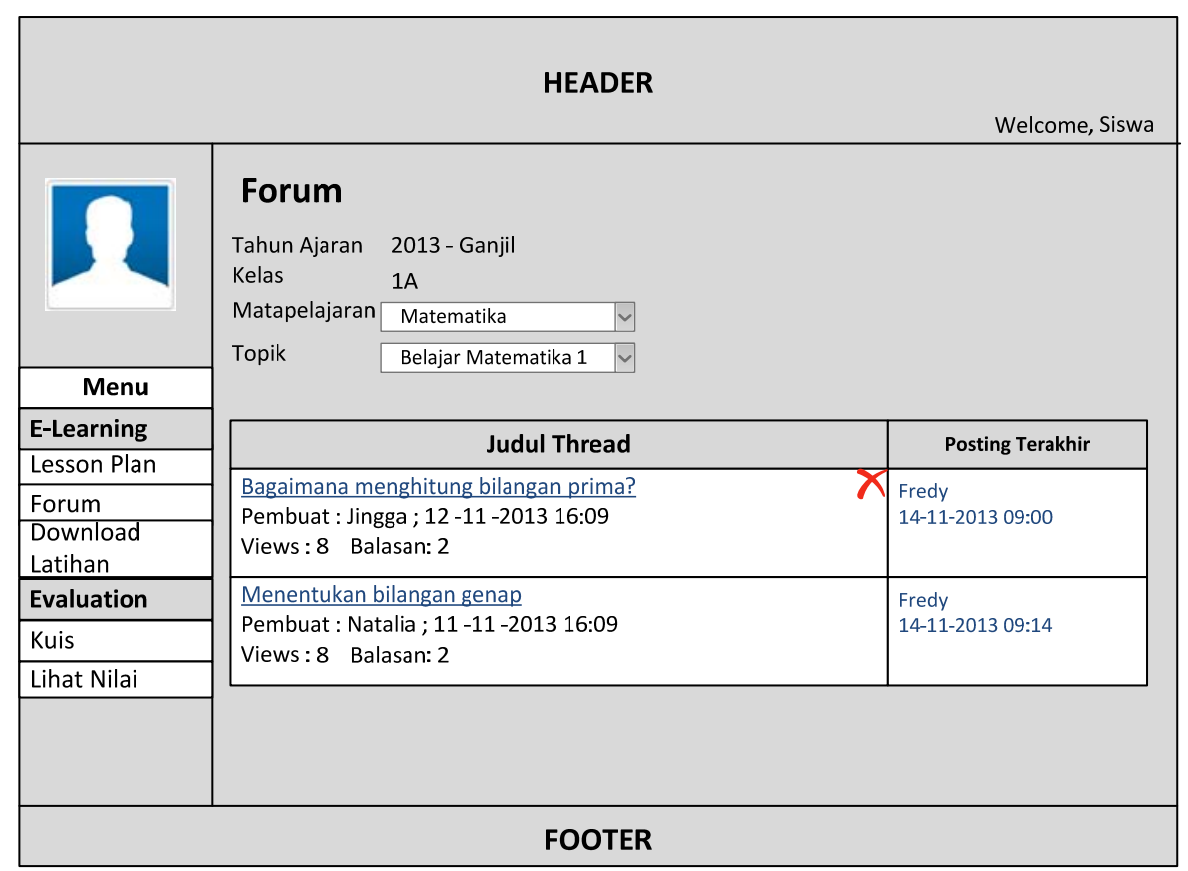

Gambar 9 Rancangan Layar Forum

\section{SIMPULAN}

Dari hasil perancangan model Learning Management System (LMS) disekolah, dapat disimpulkan sebagai berikut: (1) LMS merupakan tools atau bantuan untuk membantu guru dan siswa dalam proses pembelajaran. (2) Proses pembelajaran LMS memungkinkan para guru dan siswa untuk melakukan proses belajar mengajar tanpa dibatasi oleh ruang, dan waktu. (3) walau dengan adanya LMS bukan berarti akan menghapus proses belajar dan mengajar di kelas, karena penulis menilai proses tersebut masih merupakan proses terbaik untuk menyampaikan materi pembelajaran. Penelitian lanjutan yang bisa diperbuat adalah hasil proses pembelajaran yang menggunakan LMS tersebut dapat dibuat untuk memperkaya knowledge management system yang ada disekolah. Sekolah dapat memulai untuk memiliki knowledge menagement untuk menjadikan pengetahuan yang ada disekolah tersebut menjadi aset yang nantinya bisa berguna untuk pengembangan materi yang ada. 


\section{DAFTAR PUSTAKA}

Asiri, M. J. S. (2012). Factors Influencing the Use of Learning Management System in Saudi Arabian Higher Education: A Theoretical Framework. Canadian Center of Science and Education, 2(2).

Horton, W. (2011). E-Learning by Design. San Fransisco: John Wiley and Sons, Inc.

Nagelm, D. (2012). Technology Driving Widespread Shift in Teaching Models, diakses 11 November 2013 dari http://campustechnology.com/articles/2012/07/03/technology-driving-widespreadshift-in-teaching-models.aspx.

Rahman, KA., Ghazali, S., Ismail, N. (2010). The Effectiveness of Learning Management System (LMS) Case Study at Open University Malaysia (OUM), Kota Bharu Campus. Journal of Emerging Trends in Computing and Information Sciences, 2(2).

Satzinger, J. W., Jackson, R. B., Burd, S. D. (2012). Introduction to Systems Analysis and Design: an Agile, Iterative Approach. Canada: COUTE. 